\title{
Analysis of Phytochemistry and Antimicrobial activity of Tridax procumbens Linn
}

\author{
Ahmad Mir S ${ }^{1 *}$, Mahmood Dar A $^{2}$, Mir $\mathbf{S}^{2}$, Shabeer Ahmad $\mathbf{M}^{2}$ and Chitale $\mathbf{G}^{1}$ \\ ${ }^{1}$ Institute of Basic Sciences, Bundelkhand University, Jhansi, Uttar Pradesh, India \\ ${ }^{2}$ Department of Chemistry, Government Degree College Kulgam, University of Kashmir, Jammu and Kashmir, India
}

\begin{abstract}
The aim of the present study was to investigate the phytochemistry and bioactive nature of Tridax procumbens. The ethanol, benzene and petroleum ether extracts of dried roots of this plant were investigated for phytochemistry and antibacterial analysis. The antibacterial activity was evaluated against different bacterial strains viz. Escherichia coli, Staphylococcus aureus, Salmonella typhii, Klebsiella pneumoniae and Shigella flaxineri by detecting zone of inhibition. The zone of inhibition was compared with standard discs of Gentamicin. From these extracts, two of them (ethanolic and pet-ether extracts) revealed significant results as compared to benzene extract. The qualitative analysis revealed the presence of flavonoids, pholabatannins, resins, tannins, phenols, lipids and fats and carbohydrates.
\end{abstract}

Keywords: Tridax procumbens; Phytochemistry; Antibacterial; Zone of inhibition; Gentamicin

\section{Introduction}

India is a country rich in indigenous herbal resources which grow on their and varied topography and under changing agro climatic conditions permitting the growth of almost 20,000 plant species, of which about 2,500 are of medicinal value [1]. Tridax procumbens is a species of flowering plant belonging to family asteraceae. It is best known as widespread weed and pest plant. It is native to the tropical Americas but it has been introduced to tropical, subtropical and mild temperate regions worldwide. It is listed as a noxious weed in the United States and has a pest status. The extracts of Tridax procumbens have been reported to have various pharmacological effects, anti-inflammatory [2], hypoglycemic [3], antimicrobial [4], antioxidant [5], immunomodulatory [6], anti-diabetic [7], anti-hyperglycemic [8] and antifungal [9]. The plant bears daisy like yellow-centered white or yellow flowers with three toothed ray florets. The leaves are toothed and generally arrowhead-shaped. Its fruit is hard achene covered with stiff hairs and having a feathery, plume like white pappus at one end. Calyx is represented by scales or reduced to pappus. The plant is invasive in part because it produces so many of these achenes, upto 1500 per plant and each achene can catch the wind in its pappus and be carried to some distance. This weed can be found in fields, meadows, crop lands, disturbed areas, lawns and roadsides in areas with tropical or semitropical climate.

Tridax procumbens is employed as indigenous medicine for a variety of ailments. It has been extensively used in Indian traditional medicine for wound healing, as anticoagulant, antifungal and insect repellent, in diarrhea and dysentery. Leaf extracts are used to treat infectious skin diseases in folk medicines. It is also dispensed as 'Bhringraj' which is well known Ayurveda medicine for liver disorders. Antioxidant properties have been demonstrated, also hair growth promoting activity have been analyzed. Phytochemically limited studies reporting compounds from the roots of the plant are available. Hence the present work has been designed as to involve the preliminary investigation on the phytochemistry and antibacterial activity of Tridax procumbens.

\section{Materials and Methods}

\section{Chemicals required}

The solvents like ethanol (95\%), petroleum ether, benzene, ethyl acetate were purchased from Merck (India). The chemicals like $\mathrm{HCl}$,
Ferric Chloride, magnesium chloride and $\alpha$-napthol were taken from Sigma-Aldrich (India) and were used without further purification.

\section{Plant source}

The roots of Tridax procumbens were collected from the local area of Bundelkhand region (Bundelkhand University Campus) and were identified by Dr. Gaurav Nigam; Taxonomist, (ID NO. Bot. Ast. 09) Department of Botany; Bundelkhand University Jhansi (U.P).

Preparation of plant extracts (Soxhlet extraction): The shadedried plant material was coarsely powdered and extracted with $95 \%$ ethanol using Soxhlet apparatus for $45 \mathrm{~h}$. The solvent was changed after every $15 \mathrm{~h}$. The extract was concentrated under reduced pressure and a dark brown solid (12 g) was obtained. This ethanolic extract was then fractionated with petroleum ether, benzene and ethyl acetate on a steam bath for $8 \mathrm{~h}$. The petroleum ether extract $(3.31 \mathrm{~g})$, benzene extract $(1.5 \mathrm{~g})$ and ethyl acetate extract $(1 \mathrm{~g})$ were obtained.

Qualitative phytochemical analysis of plant extracts: The root extracts were analyzed for the Flavonoids, Pholabatannins, Resins, Lipids and Fats, Tannins, Phenols, Carbohydrates as follows [10-13].

Flavonoids (Shino or Pew test): $0.5 \mathrm{~g}$ of the extract was dissolved in $2 \mathrm{~mL}$ of ethanol and treated with few drops of conc. $\mathrm{HCl}$ and $0.5 \mathrm{~g}$ of magnesium. The pink colour was observed.

Pholabatannins: $0.5 \mathrm{~g}$ of the extract was dissolved in $2 \mathrm{~mL}$ of ethanol in a test tube, few drops of aqueous solution $\mathrm{HCl}(1 \mathrm{~g} / \mathrm{dL})$ was added and allowed. The red precipitate was observed.

Resins: $0.5 \mathrm{~g}$ of the extract was dissolved in $2 \mathrm{~mL}$ of ethanol in a test tube and treated with $2 \mathrm{~mL}$ of distilled water and observed for turbidity.

${ }^{*}$ Corresponding author: Ahmad Mir S, Institute of Basic Sciences, Bundelkhand University, Jhansi, Uttar Pradesh, India, Tel: +919906785942; E-mail: shahnawazmir11@gmail.com

Received June 16, 2016; Accepted June 25, 2016; Published June 30, 2016

Citation: Mir AS, Dar MA, Mir S, Ahmad SM, Chitale G (2016) Analysis of Phytochemistry and Antimicrobial activity of Tridax procumbens Linn. Chem Sci J 7: 132. doi:10.4172/2150-3494.1000132

Copyright: ( 2016 Mir AS, et al. This is an open-access article distributed under the terms of the Creative Commons Attribution License, which permits unrestricted use, distribution, and reproduction in any medium, provided the original author and source are credited. 
Lipids and fats: A small quantity of extract was rubbed on a filter paper and observed for a permanent translucent strain.

Tannins: $0.5 \mathrm{~g}$ of the extract was dissolved in $2 \mathrm{~mL}$ of ethanol and added with $3 \mathrm{~mL}$ of hot distilled water and then filtered. Few drops of $\mathrm{FeCl}_{3}(0.1 \mathrm{~g} / \mathrm{dL})$ were added and allowed to stand for some time and observed for brownish green or blue black colour.

Phenols: $0.5 \mathrm{~g}$ of the extract was dissolved in $2 \mathrm{ml}$ of ethanol and added with water. To this $2 \mathrm{ml}_{\text {of }} \mathrm{FeCl}_{3}$ was added and observed for the formation of green or blue colour.

Carbohydrates (Molish test): The extract $(0.5 \mathrm{~g})$ was dissolved in $2 \mathrm{~mL}$ of ethanol and added with $1 \mathrm{~mL}$ of distilled water and filtered. To this solution, 2-3 drops of $\alpha$-naphthol were added followed by $1 \mathrm{~mL}$ of $\mathrm{H}_{2} \mathrm{SO}_{4}$. The formation of violet coloured ring was observed at the interface of two layers.

\section{Antibacterial activity}

The antibacterial activity was carried out by known protocol [14]. During the activity, nutrient agar plates were prepared and stirred well till the extract was completely dissolved. Medium was then autoclaved (15 psi for $30 \mathrm{~min}$ ) and was poured on petridish plates in a laminar flow and solidified. These plates were incubated at $36^{\circ} \mathrm{C}$ for $24 \mathrm{~h}$ to check any sort of contamination. The discs were prepared from Whattmann No.1 filter paper and were sterilized. After sterilization, the moisture discs were dried. Gentamicin was taken as positive control. One set of dilution $(400 \mu \mathrm{g} / \mathrm{ml})$ of plant extracts were prepared in a suitable solvent. Three sterile filter paper discs were soaked in three solvent extracts and placed on the surface of flooded plates, marked at the back of the petri dishes. The petri dishes were incubated at $36^{\circ} \mathrm{C}$ for $24 \mathrm{~h}$.

\section{Results and Discussion}

The use of plants, both the wild and domesticated species has been recorded since ancient times in almost all major civilizations. Ayurveda has been known to be practiced in the Indian subcontinent since long. The specimen under consideration in this particular experiment has also come to notice due to its already predominant use as home strung recipe for infections. Hence the present study was carried out on Tridax procumbens Linn. Revealed the presence of bioactive constituents of medicinal value. The phytochemical compounds of the plant were qualitatively analysed and showed promising results for all the major phytochemicals. The qualitative analysis revealed the presence of flavonoids, pholabatannins, resins, tannins, phenols and carbohydrates (Table 1). The presence of these phytochemicals has also been investigated as per literature survey $[9,10,15]$. Antibacterial activity (assessed in terms of zone of inhibition) of the plant extracts, tested against selected microorganisms was recorded. In the present study three extracts from Tridex procumbens were tested for their bioactivity, among which two of them (ethanolic and pet-ether extracts) revealed significant results as compared to benzene extract. The ethanolic extract showed largest zone of inhibition ranging from 7-12 mm (Table 2; Figure 1), pet-ether extract showed 6-11 mm (Table 3; Figure 2) while as benzene extract showed 5-8 mm (Table 4; Figure 3 ), revealing its great medicinal potential for treatment of microbial induced ailments. The ethanolic extract of this plant showed highest zone of inhibition against Escherichia coli and Staphylococcus aureus ranging from 7-12 $\mathrm{mm}$, the pet-ether extract of this plant showed highest zone of inhibition against Klebsielle pneumoniae while as the benzene fraction showed the same zone of inhibition against the tested bacteria. The results were promising in relevance that pet- ether and benzene extracts were fractions of ethanolic extract.

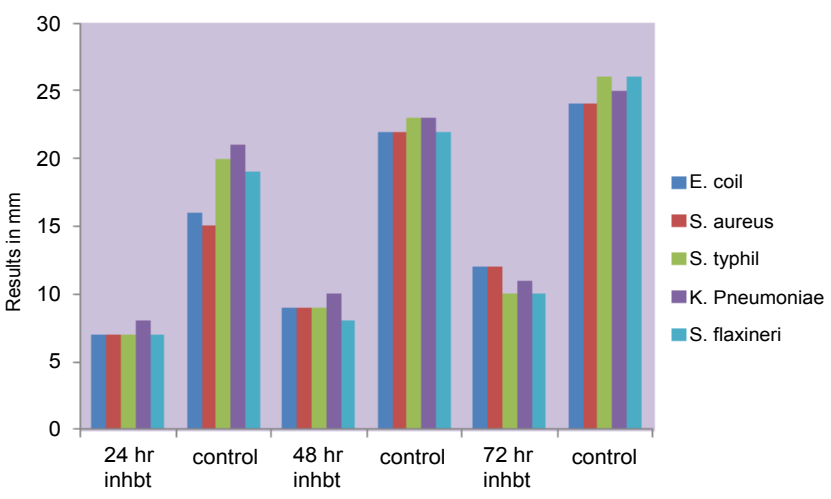

Figure 1: Showing inhibition of ethanol extract of Tridax procumbens.

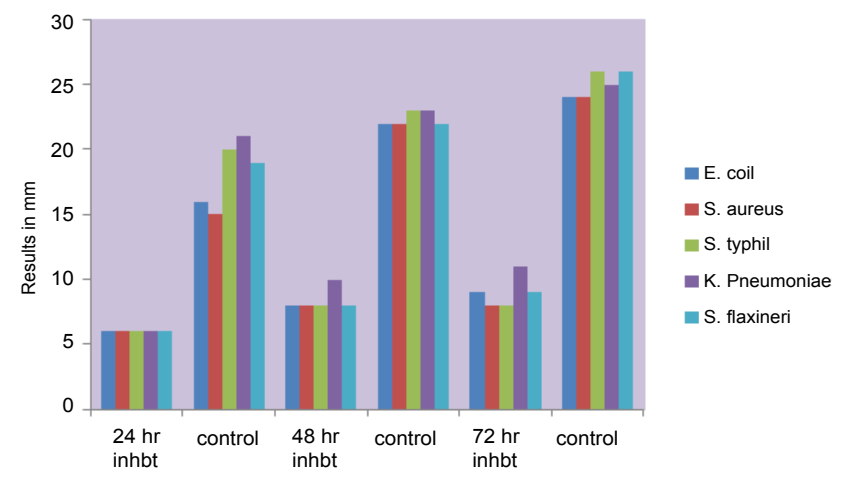

Figure 2: Showing inhibition of pet-ether fraction of ethanol extract of Tridax procumbens.

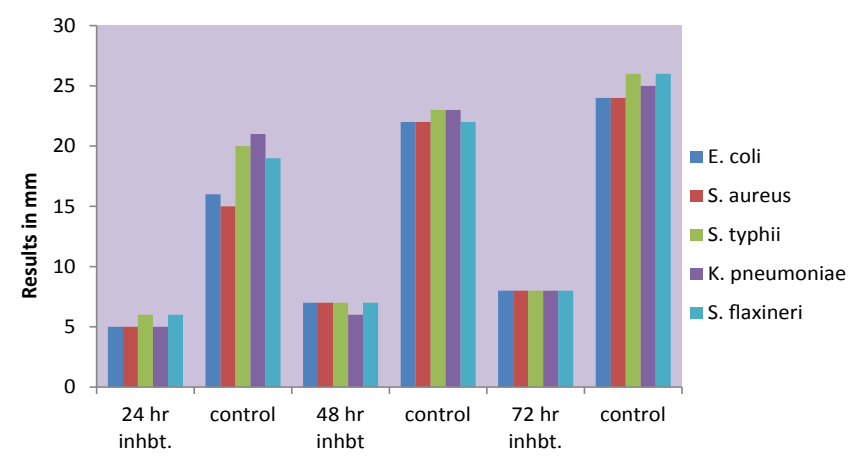

Figure 3: Showing inhibition of benzene fraction of ethanol extract of Tridax procumbens.

\begin{tabular}{|c|c|c|}
\hline S No & Name of the test & Ethanolic extract \\
\hline 1 & Flavonoids & + \\
\hline 2 & Pholabatannins & + \\
\hline 3 & Resins & + \\
\hline 4 & Lipids and fats & + \\
\hline 5 & Tannins & + \\
\hline 6 & Phenols & + \\
\hline 7 & Carbohydrates & + \\
\hline
\end{tabular}

$(+)=$ Presence

Table 1: Showing the qualitative phytochemical analysis of root extract of Tridex procumbens. 


\begin{tabular}{|c|c|c|c|c|c|c|}
\hline \multirow[b]{2}{*}{ Cultures } & \multicolumn{2}{|c|}{24 hours of inhibition } & \multicolumn{2}{|c|}{48 hours of inhibition } & \multicolumn{2}{|c|}{72 hours of inhibition } \\
\hline & $(400 \mu \mathrm{g} / \mathrm{ml})$ & $\begin{array}{l}\text { Gentamicin } \\
\text { (Control) }\end{array}$ & $(400 \mu \mathrm{g} / \mathrm{ml})$ & $\begin{array}{l}\text { Gentamicin } \\
\text { (Control) }\end{array}$ & $(400 \mu \mathrm{g} / \mathrm{ml})$ & $\begin{array}{c}\text { Gentamicin } \\
\text { (Control) }\end{array}$ \\
\hline Escherichia coli & 7 & 16 & 9 & 22 & 12 & 24 \\
\hline $\begin{array}{c}\text { Staphylococcus } \\
\text { aureus }\end{array}$ & 7 & 15 & 9 & 22 & 12 & 24 \\
\hline Salmonella typhii & 7 & 20 & 9 & 23 & 10 & 26 \\
\hline Klebsiella pneumoniae & 8 & 21 & 10 & 23 & 11 & 25 \\
\hline Shigella flaxineri & 7 & 19 & 8 & 22 & 10 & 26 \\
\hline
\end{tabular}

Table 2: Showing zone of inhibition $(\mathrm{mm})$ of ethanolic extract of Tridax procumbens.

\begin{tabular}{|c|c|c|c|c|c|c|}
\hline \multirow[b]{2}{*}{ Cultures } & \multicolumn{2}{|c|}{24 hours of inhibition } & \multicolumn{2}{|c|}{48 hours of inhibition } & \multicolumn{2}{|c|}{72 hours of inhibition } \\
\hline & $(400 \mu \mathrm{g} / \mathrm{ml})$ & $\begin{array}{c}\text { Gentamicin } \\
\text { (Control) }\end{array}$ & $(400 \mu \mathrm{g} / \mathrm{ml})$ & $\begin{array}{l}\text { Gentamicin } \\
\text { (Control) }\end{array}$ & $(400 \mu \mathrm{g} / \mathrm{ml})$ & $\begin{array}{c}\text { Gentamicin } \\
\text { (Control) }\end{array}$ \\
\hline Escherichia coli & 6 & 16 & 8 & 22 & 9 & 24 \\
\hline $\begin{array}{c}\text { Staphylococcus } \\
\text { aureus }\end{array}$ & 6 & 15 & 8 & 22 & 8 & 24 \\
\hline Salmonella typhii & 6 & 20 & 8 & 23 & 8 & 26 \\
\hline Klebsiella pneumoniae & 6 & 21 & 10 & 23 & 11 & 25 \\
\hline Shigella flaxineri & 6 & 19 & 8 & 22 & 9 & 26 \\
\hline
\end{tabular}

Table 3: Zone of inhibition $(\mathrm{mm})$ of pet-ether fraction of ethanolic extract of Tridax procumbens.

\begin{tabular}{|c|c|c|c|c|c|c|}
\hline \multirow[b]{2}{*}{ Cultures } & \multicolumn{2}{|c|}{24 hours of inhibition } & \multicolumn{2}{|c|}{48 hours of inhibition } & \multicolumn{2}{|c|}{72 hours of inhibition } \\
\hline & $(400 \mu \mathrm{g} / \mathrm{ml})$ & $\begin{array}{c}\text { Gentamicin } \\
\text { (Control) }\end{array}$ & $(400 \mu \mathrm{g} / \mathrm{ml})$ & $\begin{array}{l}\text { Gentamicin } \\
\text { (Control) }\end{array}$ & $(400 \mu \mathrm{g} / \mathrm{ml})$ & $\begin{array}{c}\text { Gentamicin } \\
\text { (Control) }\end{array}$ \\
\hline Escherichia coli & 5 & 16 & 7 & 22 & 8 & 24 \\
\hline $\begin{array}{c}\text { Staphylococcus } \\
\text { aureus }\end{array}$ & 5 & 15 & 7 & 22 & 8 & 24 \\
\hline Salmonella typhii & 6 & 20 & 7 & 23 & 8 & 26 \\
\hline Klebsiella pneumoniae & 5 & 21 & 6 & 23 & 8 & 25 \\
\hline Shigella flaxineri & 6 & 19 & 7 & 22 & 8 & 26 \\
\hline
\end{tabular}

Table 4: Zone of inhibition $(\mathrm{mm})$ of benzene fraction of ethanolic extract of Tridax procumbens.

The possible mechanisms for its antibacterial activity may be due to enzyme inhibition, substrate deprivation, complex with cell wall, membrane disruption, metal-ion complexation, intercalates into cell wall and DNA of parasites. Resistance of microorganisms to many antibiotics has resulted in morbidity and mortality from treatment failure and increased health care costs. Though many antibiotics are available but multidrug resistance has encouraged search for new, safe and effective bio active agents of herbal origin. Most of the secondary metabolites were identified in the polar extracts. The concentration of polar metabolites is higher than the non-polar metabolites. Flavonoids are known to be synthesized by plants in response to microbial infection; hence it should not be surprising that they have been found to be effective in-vitro antibacterial substances against a wide array of infectious agents [16]. Tannins (commonly referred as tannic acid) are also known potential antimicrobial agents. They are water soluble polyphenols present in many plants. Tannins have been reported to prevent the development of microorganisms by precipitating microbial protein, the growth of many fungi, yeasts, bacteria and viruses were inhibited by this group of compounds. They show physiological effects like antisecretolytic, antiphlogistic, anti-microbial and antiparasatic effects [15]. Phytotherapeutically, tannin containing plants are used to treat nonspecific diarrhea, inflammation of mouth, throat and slightly injured skins [17]. Since from ancient times, the leaf juice of Tridax procumbens was shown to depress wound contraction in experimented animals. In addition to the possible antibacterial behavior, it was suggested that involvement of complex interaction between epidermal and dermal cells, the extra cellular matrix, controlled angiogenesis and plasma derived proteins coordinated by an array of cytokines and growth factors [18]. Tridax procumbens antagonized antiepithelization and tensile strength depressing effect of dexamethasone (a known healing suppressant agent) without affecting anticontraction and antigranulation action of dexamethasone. Aqueous extract was also effective in increasing lysyl oxidase but to a lesser degree than whole plant extract. Further it has been shown that extract of leaves of this plant also promotes wound healing in normal and immune compromised (steroid treated) rats. The plant increase not only lysyl oxidase but also, protein and nucleic acid content in the granulation tissue, probably as a result of increase in glycosaminoglycan content [19].

\section{Conclusions}

Tridax procumbens Linn. is widely distributed weed. Each and every part of it is useful having pharmacological activity. The plant product over synthetic compound is the need in treatment of diseases, as it does not have any deleterious effect in higher animals including man. The work done showed that the different extracts of plant have potential antibacterial activity. The qualitative analysis revealed the presence of the biomolecules such as flavonoids, Pholabatannins, resins, lipids and fats, phenolic compounds, saponins, steroids, tannins and terpenoids. The studies on plant Tridax procumbens also desire development of novel therapeutic agents from the various types of compounds by means of modification and derivatization to design more potent and selective therapeutic agents. Therefore, there is huge room for research in direction of more pharmacological activities of plant and to elucidate the mechanism of action of same in future. 
Citation: Mir AS, Dar MA, Mir S, Ahmad SM, Chitale G (2016) Analysis of Phytochemistry and Antimicrobial activity of Tridax procumbens Linn. Chem Sci J 7: 132. doi:10.4172/2150-3494.1000132

\section{Acknowledgements}

Authors thank Head of Department of Chemistry, Bundelkhand University Jhansi for providing the necessary research facilities. Author (SAM) specially thank Department of Biomedical Sciences and Department of Botany, Bundelkhand University, Jhansi for biological screening of the plant extract.

\section{References}

1. Choudhari MM, Maheshwari JK (2009) Ethanobotany in South Asia, middile East. Journal of Scientific Research 4: 144-146.

2. Prakash VD, Iravati K, Margaret I, Sattur PB (1989) Phamacology and biochemical evaluation of Tridax procumbens in inflammation. Indian Journal of pharmacology 21: 17.

3. Kalaya A, Orasa P, Uraiwan P (1997) Hypoglycemic activity of Tridax procumbens in rats. Thai Journal of Pharma Science 21: 211-221.

4. Taddei A, Rosas-Romero AJ (2000) Bioactivity studies of extracts from Tridax procumbens. Phytomedcine 7: 235-238.

5. Viluvanthan R, Kanchi SS, Thiruvengadam D (2004) Effect of Tridax procumbens on liver antioxidant defence system during lipopolysacharideinduced hepatitis in D-galactosomine senitized rats. Molecular and Cellular Biochemistry 269: 131-136.

6. Olandunmoye MK (2006) Immunomodulatory effects of ethanolic extract of Tridax procumbens on swiss albino rats orogastrically dosed with Pseudomonas aeruginosa. Trends in Medical Research 1: 152-155.

7. Durgacharan AB, Suresh GK, Rahul SA (2008) Antidiabetic activity of lea extracts of Tridax procumbens. Indian Journal of Green Pharmacy 2: 126-128.

8. Hemant P, Sameer S, Balwant SK, Kusum J, Jain GE (2009) Evaluation of hypoglycemic and anti-hyperglycemic of Tridax procumbens. BMC Complement Altern Med 9: 48 .
9. Sandeep A, Srivastava RC (2010) Antifungal property of Tridax procumbens against three phytopathogenic fungi. Arch Pharmacy Scientific Research 2: 258-263.

10. Manjamalia A, Sardar R, Sathyajith S, Guruvayooroppan C, Berlin GVM (2010) Analysis of phytochemical constituents and antimicrobial activity of some medicinal plants. Global journal of Biotechnology and Biochemistry 5: 120-128.

11. Sofowora A (1993) Medicinal plants and Traditional Medicine in Africa. John Wiley and Son Ltd., pp: 150-153.

12. Trease GE, Evans WC (1989) Pharmocognosy. 11th edn. Brailiar Tiridel and MacMillan Publishers, London, UK, pp: 155-265.

13. Herborne JB (1973) Phytochemical Methods. 3rd edn. Chapman and Hall Ltd., London, pp: 135-203.

14. Parekh J, Chanda S (2006) In-vitro antimicrobial activities of Launaea procumbens, Vitisvinifera and Cyperus rotundus. African Journal of Biomedicine Research 9: 89-93.

15. Dhanabalan R, Doss A, Jagadeeswari M, Ballachander S, Kezia E, et al (2008) In vitro phytochemical screening and antibacterial activity of aqueous and methanolic extract of Tridax procumbens against bovine mastitis isolated Staphylococcus aurens. Ethanobotinical leaflets 12: 1090-1095

16. Jamine R, Daisy P, Selvekumar BN (2007) Against ESL-producing multi drug resistant anteric bacteria. Research journal of Microbiology 2: 369-374.

17. Naveen PR, Vishwanthan S, Renuka DJ, Vijayashree N, Sweth VC, et al. (2008) Priliminary phytochemical screening and antimicrobial activity of Somanea saman. Journal of Medicinal plant Research 2: 268-270.

18. Bhat RS, Shankrappa J, Shivakumar HG (2007) Formulation and evaluation of polyherbal wound treatments. Asian Journal of Pharmaceutical Sciences 2: 11-17.

19. Nia R, Paper DH, Essien EE, Oladimeji OH, Iyadi KC, et al. (2003) Investiagation into in-vitro radical scavaging and in-vivo anti-inflammatory potential of Tridax procumbens. Nigerian Journal of Physiological Science 18: 39-43. 